own chances of winning, Milan allowed others to win as well. When it came his turn to deal, he always dealt a hand of Prague. In cards, as in all things, Milan Hapala was scholar and a gentleman.

JEFFREY KEY Sweet Briar College

\title{
DONALD STONE MACDONALD
}

$$
\text { (1919-1993) }
$$

Donald S. Macdonald died on August 29, 1993, in Washington, D.C., at the age of 74 . He was a specialist in Korean affairs, especially in the area of KoreanAmerican relations. Professor Macdonald at his death had a nearly fifty-year continuous involvement in Korea, dating from 1945 and the U.S. military occupation. For a period during the U.S. occupation, he served as the mayor of Kwangju.

Born in Boston in 1919, Donald Macdonald had two careers, both centering on Korea. He was first a career officer at the Department of State, and then undertook a rewarding academic career. Educated at the Massachusetts Institute of Technology (B.A.), Harvard University (M.A., Political Science), and George Washington University (Ph.D., Political Science), his career at the State Department centered both in and on Korea. In the State Department, he served as Director of the Korea Desk and in the Bureau of Intelligence and Research in Washington, as well as in Seoul. He received the Department's Superior Honor Award three times, and was given the John Jacobs Rogers Award for Distinguished Service. In addition to his stations in Korea, he served in the Foreign Service in Turkey and Switzerland.

Professor Macdonald taught at East Stroudsberg University in Pennsylvania from 1971 to 1980 . In 1983, he founded the Korea program at Georgetown University, in which he still taught at his death. In addition to his formal academic contributions, Macdonald directed Korean area studies at the Foreign Service Institute of the State Department for a number of years. In the 1960s, he was a founder of the continuing Washington Korea Tuesday Luncheon Group, and was prominent in international conferences and symposia on Korea.

Macdonald was a past president of the MidAtlantic Region of the AAS, and later worked on its membership committee and in revising its by-laws. He was the founder and editor of the MidAtlantic Bulletin of Korean Studies. He constantly sought to expand knowledge of Korea and Asia within the academic community, into the school systems, and among the general public. He was the driving force for establishing the Wineck Prize for the best secondary school essay on Asian studies in the 
MidAtlantic region, and worked to further knowledge of Korea outside specialist circles.

Macdonald's college text, The Koreans: Contemporary Politics and Society (Westview Press, 1988, second edition 1990), is considered the most popular college text on the subject. A third edition is planned under the editorship of Donald Clark of Trinity University, whom Professor Macdonald designated to perform that task when he became aware his illness was terminal. He is also the author of U.S.-Korea Relations from Liberation to Self-Reliance (Westview, 1992), a product of a classified study he completed for the State Department. At his death, he had partly completed a book on Korean politics, for which he had received a Fulbright Scholarship to Korea.

Macdonald was a founder of Senior International Resources, a non-profit consulting firm. His social and educational concerns were reflected in his donations of time and funds for all types of outreach activities. He will be remembered in Washington not only for his Korean activities, but also for his unstinting devotion to the betterment of the civic neighborhood in which he lived. He will be remembered, by his students, his neighbors, and the profession, as both dedicated and concerned.

DAvid I. SteinberG Georgetown University 